\title{
Pengaruh Motivasi dan Kebiasaan Belajar Terhadap Hasil Belajar Matematika Siswa Kelas XI SMAN 1 Jonggat
}

\author{
Sripatmi, Baidowi, Fitriani
}

Pendidikan Matematika, FKIP, Universitas Mataram, Mataram

e-mail: fitrisanariego13@gmail.com

\begin{tabular}{|c|c|}
\hline INFORMASI ARTIKEL & ABSTRACT \\
\hline $\begin{array}{l}\text { Keywords: } \\
\text { Learning Motivation; } \\
\text { Learning Habits; } \\
\text { Mathematics Learning } \\
\text { Outcomes } \\
\text { Kata Kunci: } \\
\text { Motivasi Belajar; } \\
\text { Kebiasaan Belajar; } \\
\text { Hasil Belajar } \\
\text { Matematika } \\
\text { Cara Mengutip: } \\
\text { Sripatmi, Baidowi \& } \\
\text { Fitriani. (2019). } \\
\text { Pengaruh Motivasi dan } \\
\text { Kebiasaan Belajar } \\
\text { Terhadap Hasil } \\
\text { Belajar Matematika } \\
\text { Siswa Kelas XI SMAN } \\
1 \text { Jonggat.1(2), 104- } \\
112 .\end{array}$ & 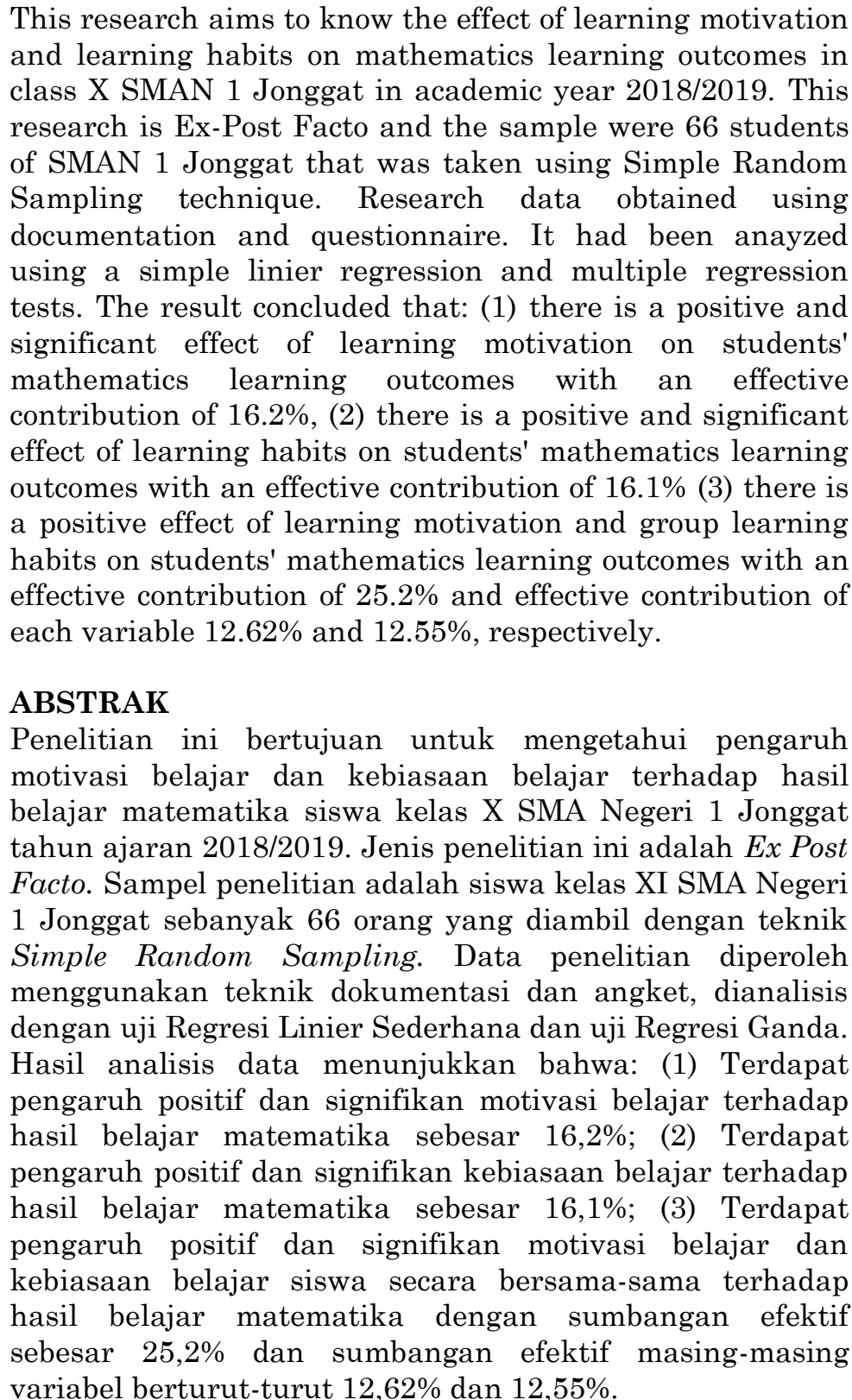 \\
\hline
\end{tabular}




\section{Pendahuluan}

Keberhasilan dalam peningkatan mutu pendidikan dapat dilihat dari hasil belajar siswa. Hasil belajar merupakan tolak ukur yang digunakan untuk menentukan tingkat keberhasilan siswa dalam mengetahui dan memahami suatu mata pelajaran yang biasanya dinyatakan dengan nilai yang berupa huruf atau angkaangka. Hasil belajar siswa adalah kemampuan yang diperoleh anak setelah melalui kegiatan belajar [1].

Berdasarkan informasi yang diperoleh dari guru yang mengajar pada mata pelajaran matematika kelas XI di SMA Negeri 1 Jonggat didapatkan data nilai siswa pada mata pelajaran matematika masih tergolong rendah. Hasil belajar yang dicapai siswa dipengaruhi oleh dua faktor utama, yakni faktor yang berasal dari dalam diri siswa dan faktor yang datang dari luar diri siswa atau faktor lingkungan [2]. Faktor yang datang dari diri siswa diantaranya terdapat faktor motivasi belajar dan kebiasaan belajar. Berdasarkan hasil observasi di SMA Negeri 1 Jonggat pada tanggal 5 April 2018 didapati bahwa SMA Negeri 1 Jonggat memiliki sarana dan prasarana yang cukup menunjang kelancaran Kegiatan Belajar Mengajar (KBM). Namun aktifitas belajar sebagian siswa di SMA Negeri 1 Jonggat masih rendah. Hal ini dapat dilihat dari masih adanya siswa yang tidak mencacat apa yang disampaikan guru.

Berdasarkan pendapat beberapa ahli, menyatakan bahwa ketiadaan ketertarikan terhadap suatu mata pelajaran menjadi pangkal penyebab kenapa siswa tidak mencatat apa yang disampaikan guru [3]. Itulah sebagai pertanda bahwa siswa tidak mempunyai motivasi untuk belajar. Jika siswa tidak dapat mengatasi masalah internnya, seperti konsentrasi belajar, motivasi belajar, rasa percaya, kebiasaan belajar dan lain-lain, maka ia tidak belajar dengan baik. Motivasi belajar dapat diartikan sebagai keseluruhan daya penggerak sikis dalam diri siswa yang menimbulkan kegiatan belajar, menjamin kelangsungan kegiatan belajar dan memberikan arah pada kegiatan belajar demi mencapai suatu tujuan [4]. Sedangkan belajar matematika adalah belajar tentang konsep-konsep dan struktur matematika yang terdapat dalam materi yang dipelajari serta mencari hubungan antara konsep-konsep dan struktur-struktur matematika [5]. Sehingga dapat disimpulkan, motivasi belajar matematika adalah keseluruhan daya penggerak dalam diri individu yang mendorong individu mengadakan perubahan sikap dan perilaku untuk belajar matematik. Jika tidak ada motivasi dalam diri siswa untuk belajar matematika maka selamanya siswa tidak akan tertarik untuk belajar matematika dan tidak memperoleh kepuasan dari belajarnya sehingga belajar menjadi tidak bermakna. Kenyataan yang terjadi dalam proses pembelajaran matematika bahwa jika tidak ada konsekuensi tugas harus dikumpulkan maka akan ada sebagian kecil saja yang akan mengerjakan tugas. Hal lainnya, apabila siswa diminta maka akan terjadi sebaliknya. Jika tugas yang diberikan tersebut tugas yang dapat mereka kerjakan maka motivasinya akan 
meningkat namun yang akan terjadi sebaliknya jika tugas yang diberikan terasa sulit. Hal inilah yang menjadi kebiasaan siswa yang kurang baik dalam belajar.

Salah satu faktor lain yang penting dalam mempengaruhi hasil belajar adalah kebiasaan belajar. Kebiasaan belajar yang baik tidak dibentuk dalam waktu yang singkat akan tetapi dapat ditumbuhkan sedikit-demi sedikit. Kebiasaan belajar adalah suatu cara atau teknik yang menetap pada diri siswa waktu menerima pelajaran, membaca buku, mengerjakan tugas, dan pengaturan waktu untuk menyelesaikan kegiatan [6]. Siswa dapat dikatakan memiliki kebiasaan yang baik apabila dia mampu memilih cara-cara belajar yang benar-benar mendukungnya untuk belajar. Belajar matematika harus bertahap dan beruntun serta mendasar kepada pengalaman belajar yang lalu, maka belajar matematika yang terputusputus akan mengganggu terjadinya proses pemahaman terhadap topik yang sedang dipelajari. Ini berarti proses belajar matematika akan terjadi dengan lancar jika belajar itu sendiri dilakukan secara kontinu. Kontinuitas belajar merupakan manifestasi dari kebiasaan belajar sebagai upaya untuk memperoleh keterampilan menjalankan prosedur dan operasi dalam matematika secara cepat dan benar. Keterampilan yang dimiliki siswa didasarkan atas pemahaman sterhadap konsep dan teorema yang telah dipelajarinya dan atas pemahamannya ini siswa melakukan latihan yang cukup. Dengan latihan yang cukup siswa tidak mudah melupakan konsep dan teorema yang telah dipelajari. Dengan demikian terlihat adanya kaitan antara kontinuitas belajar matematika sebagai manifestasi dari kebiasaan belajar dengan proses belajar matematika.

Oleh karena motivasi dan kebiasaan belajar memegang peranan penting dalam mencapai suatu target yang telah ditentukan, maka diharapkan siswa yang memiliki motivasi belajar yang rendah dan kebiasaan belajar yang tidak baik dapat menyadari bahwa hal tersebut masih bisa diperbaiki dan diatasi, karena tergolong faktor non-intelektual yang artinya masih bisa dihilangkan dengan usaha-usaha tertentu sehingga akan terciptanya situasi pembelajaran yang kondusif sehingga hasil belajar pun tercapai dengan maksimal.

Oleh karena itu, penelitian ini bertujuan untuk mengetahui i) pengaruh motivasi belajar terhadap hasil belajar matematika, ii) pengaruh kebiasaan belajar terhadap hasil belajar matematika, iii) pengaruh bersama-sama antara motivasi belajar dan kebiasaan belajar terhadap hasil belajar matematika pada siswa kelas X SMA Negeri 1 Jonggat tahun ajaran 2018/2019.

\section{Metode}

Penelitian ini merupakan penelitian Ex Post Facto. Sampel penelitian adalah siswa kelas XI SMA Negeri 1 Jonggat sebanyak 66 orang yang diambil dengan teknk Simple Random Sampling dengan tingkat kesalahan pengambilan sampel adalah 5\%. Teknik pengumpulan data yang digunakan adalah dokumentasi dan angket yang telah diuji validitas serta reliabilitasnya untuk memperoleh data 
motivasi belajar, kebiasaan belajar dan test untuk hasil belajar matematika. Angket yang digunakan merupakan angket tertutup dengan teknik penskoran Likert. Untuk menggambarkan hasil data yang diperoleh digunakan pengkategorian dengan pedoman statistik hipotetik. Selanjutnya hasil penilaian dengan angket dan nilai test hasil belajar dianalisis dengan teknik analisis data deskriftif dan analisis inferensial dengan uji hipotesis menggunakan uji regresi linier sederhana dan uji regresi ganda.

\section{Hasil dan Pembahasan}

Berdasarkan data yang diperolehh dari hasil pengumpulan data angket dan test hasil belajar matematika siswa, diperoleh gambaran data pada gambar 1 , sebagai berikut:

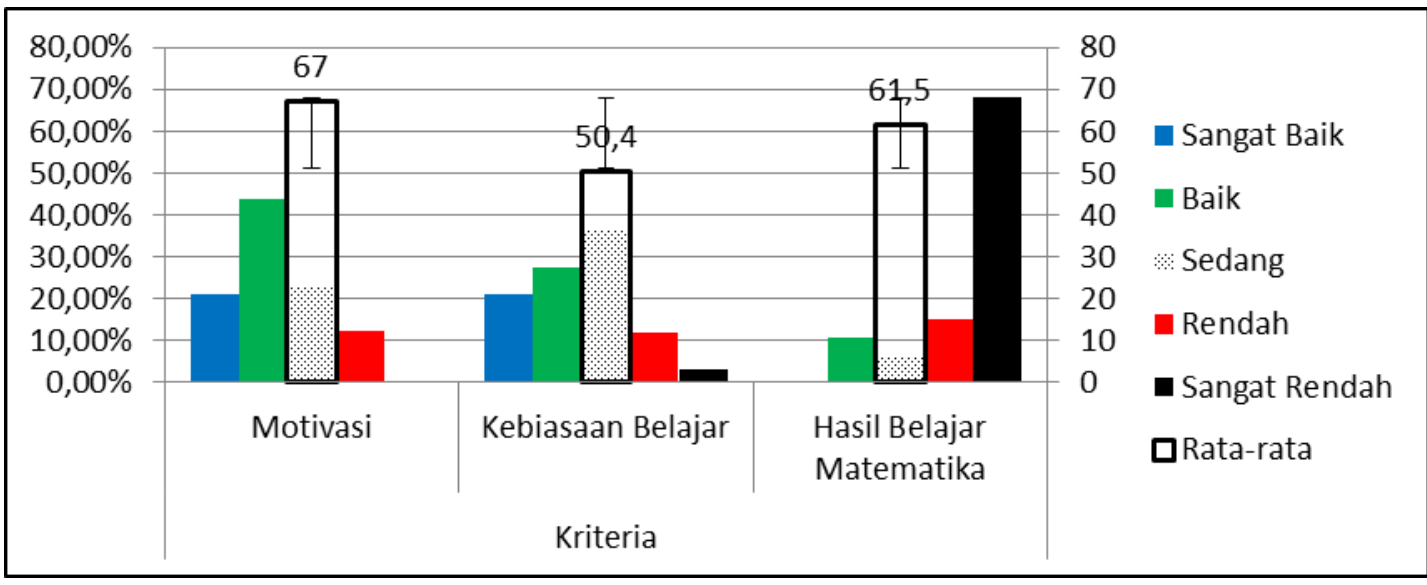

Gambar 1. Persentase Kategori Motivasi Belajar, Kebiasaan Belajar Dan Hasil Belajar Matematika

Dari gambar 1 dapat dilihat secara umum ketegori motivasi belajar secara umum tergolong dalam kategori tinggi dan rata-rata dalam kategori tinggi. Kategori kebiasaan belajar tergolong dalam kategori cukup baik dan rata-rata dalam kategori baik. Dan kategori hasil belajar dalam kategori sangat rendah dan ratarata dalam kategori sangat rendah juga.

Sebelum dilakukan uji hipotesis, dilakukan uji asumsi yaitu normalitas, liinieritas, multikolinieritas dan heteroskedasitas. Dari hasil uji asumsi disimpulkan bahwa data yang diperoleh normal, linier, tidak terdapat masalah multikolinieritas dan tidak terjadi heteroskedasitas. Untuk uji hipotesis yang pertama dan kedua menggunakan analisis korelasi tunggal dan hipotesis ketiga menggunakan uji regresi ganda.

\subsection{Analisis Korelasi Tunggal Antara Motivasi Belajar $\left(\mathrm{X}_{1}\right)$ Terhadap Hasil Belajar Matematika (Y)}

Melihat adanya pengaruh motivasi siswa terhadap hasil belajar matematika digunakan korelasi tunggal dengan uji $\mathrm{F}$ dan diperoleh $\mathrm{F}_{\text {hitung }}>\mathrm{F}_{\text {tabel }}$ pada taraf 
signifikansi 5\%. Didapatkan $\mathrm{F}_{\text {hitung }}$ sebesar 12,3 dan $\mathrm{F}_{\text {tabel }}=3,99$, sehingga $\mathrm{H}_{\mathrm{a}}$ diterima dan $\mathrm{H}_{0}$ ditolak. Artinya terdapat pengaruh yang signifikan antara motivasi belajar terhadap hasil belajar matematika siswa. Besarnya pengaruh ini dituliskan dalam pesamaan garis regresi $\mathrm{Y}=23+0,58 \mathrm{X}_{1}$. Persamaan regresi ini dapat diartikan bahwa, bila nilai motivasi belajar $\left(\mathrm{X}_{1}\right)$ bertambah 1 poin, maka nilai hasil belajar siswa akan bertambah 0,58. Apabila nilai motivasi belajar $\left(\mathrm{X}_{1}\right)$ sebesar nol, maka nilai hasil belajar matematika siswa adalah 23 .

Berdasarkan hasil penelitian pada dapat dilihat juga bahwa nilai korelasi $(R)$ dari analisis regresi yang dilakukan adalah sebesar 0,402. Karakteristik nilai Guilford menggolongkan 0,402 sebagai hubungan dalam tingkat yang sedang. Artinya motivasi mempunyai hubungan yang sedang dengan hasil belajar matematika siswa. Karena koefisien korelasi bernilai positif, maka dapat dikatakan bahwa koefisien korelasi antara motivasi dan hasil belajar matematika bersifat positif. Hal ini berarti apabila motivasi belajar tinggi maka akan memberikan peningkatan terhadap hasil belajar matematika siswa. Akan tetapi karakteristik nilai korelasi Guilford menunjukkan bahwa nilai determinasi sebesar 0,161 termasuk dalam karakteristik sangat lemah artinya pengaruh yang diberikan motivasi terhadap hasil belajar masih lemah. Artinya motivasi siswa untuk belajar matematika masih rendah, hal ini akan menentukan intensitas usaha belajar bagi para siswa. Namun, jika ditinjau dengan faktor lain, yang belum dijelaskan dalam penelitian ini bisa saja menambah pengaruh atau malah menurunkan pengaruh motivasi terhadap hasil belajar matematika. Berdasarkan hasil uji tersebut, dapat disimpulkan bahwa terdapat pengaruh positif motivasi terhadap hasil belajar matematika. Penelitian ini didukung juga oleh penelitian sebelumnya yang menghasilkan kesimpulan bahwa motivasi belajar siswa berpengaruh positif terhadap hasil belajar matematika [7].

\subsection{Analisis Korelasi Tunggal Antara Kebiasaan Belajar $\left(\mathrm{X}_{2}\right)$ Terhadap Hasil Belajar Matematika (Y)}

Berdasarkan hasil analisis dapatkan hasil $\mathrm{F}_{\text {hitung }}>\mathrm{F}_{\text {tabel }}$ pada taraf signifikansi 5\%.

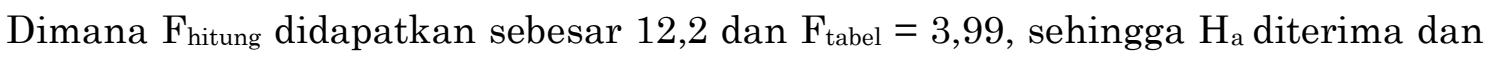
$\mathrm{H}_{0}$ ditolak. Artinya terdapat pengaruh yang signifikan antara kebiasaan belajar terhadap hasil belajar matematika siswa. Besarnya pengaruh ini dituliskan dalam pesamaan garis regresi $\mathrm{Y}=26+0,71 \mathrm{X}_{2}$. Persamaan regresi ini dapat diartikan bahwa, bila nilai kebiasaan belajar $\left(\mathrm{X}_{2}\right)$ bertambah 1 poin, maka nilai hasil belajar siswa akan bertambah 0,71. Apabila nilai kebiasaan belajar $\left(\mathrm{X}_{2}\right)$ sebesar nol, maka nilai hasil belajar matematika siswa adalah 26 .

Berdasarkan hasil penelitian dapat dilihat bahwa nilai korelasi (R) dari analisis regresi yang dilakukan adalah sebesar 0,401. Karakteristik nilai Guilford menggolongkan 0,401 sebagai hubungan dalam tingkat yang sedang. Artinya kebiasaan belajar juga mempunyai hubungan yang sedang dengan hasil belajar 
matematika siswa. Karena koefsien korelasi bernilai positif, maka dapat dikatakan bahwa koefisien korelasi antara kebiasaan belajar dan hasil belajar matematika bersifat positif. Implikasi dari penelitian ini adalah semakin baik kebiasaan belajar maka akan semakin dapat meningkatkan hasil belajar siswa. Namun, karakteristik nilai Guiford menunjukkan bahwa nilai determinasi 0,16 termasuk dalam karakteristik sangat lemah artinya pengaruh yang diberikan kebiasaan belajar terhadap hasil belajar masih rendah. Namun, jika ditinjau dengan faktor lain, yang belum dijelaskan dalam penelitian ini bisa saja menambah pengaruh atau malah menurunkan pengaruh kebiasaan belajar terhadap hasil belajar matematika. Kebiasaan belajar sangat berperan penting dalam mencapai hasil belajar matematika. Dengan kebiasaan belajar yang baik maka siswa akan mendapatkan hasil belajar yang baik. Begitupun sebaliknya jika kebiasaan belajar siswa tidak baik maka hasil belajar yang didapat siswa akan rendah. Berdasarkan hasil uji tersebut, dapat disimpulkan bahwa terdapat pengaruh positif kebiasaan belajar terhadap hasil belajar matematika. Sejalan dengan itu, dalam penelitian lainnya menghasilkan kesimpulan bahwa motivasi mempunyai pengaruh yang positif terhadap hasil belajar matematika [8].

\subsection{Analisis Regresi Ganda Antara Motivasi Belajar $\left(\mathrm{X}_{1}\right)$ dan Kebiasaan Belajar $\left(\mathrm{X}_{2}\right)$ Terhadap Hasil Beljar Matematika (Y)}

Melihat pengaruh motivasi dan kebiasaan belajar siswa secara simultan (bersamasama) terhadap hasil belajar matematika digunakan analisis regresi ganda dengan

uji $\mathrm{F}$ dan diperoleh hasil $\mathrm{F}_{\text {hitung }}>\mathrm{F}_{\text {tabel }}$ pada taraf signifikansi 5\%. $\mathrm{F}_{\text {hitung }}$ didapatkan sebesar 10,61 dan $\mathrm{F}_{\text {tabel }}=3,14$, sehingga $\mathrm{H}_{\mathrm{a}}$ diterima dan $\mathrm{H}_{0}$ ditolak. Hasil penelitian ini menunjukkan bahwa kedua prediktor secara bersama-sama ada pengaruh yang signifikan terhadap hasil belajar matematika. Sejalan dengan pendapat ini, sebuah penelitian menghasilkan kesimpulan bahwa terdapat pengaruh yang signifikan antara motivasi dan kebiasaan belajar terhadap hasil belajar matematika [9]. Analisis data menunjukkan besarnya hubungan ini dituliskan dalam pesamaan garis regresi $\mathrm{Y}=3,16+0,45 \mathrm{X}_{1}+0,56 \mathrm{X}_{2}$. Persamaan tersebut menunjukkan bahwa nilai koefisien regresi $\mathrm{X}_{1}$ sebesar 0,45 , artinya apabila motivasi belajar $\left(\mathrm{X}_{1}\right)$ meningkat 1 poin maka akan terjadi pertambahan nilai pada hasil belajar matematika (Y) sebesar 0,45 dengan asumsi kebiasaan belajar $\left(\mathrm{X}_{2}\right)$ tetap. Begitu pula dengan kebiasaan belajar, nilai koefisien regresi kebiasaan belajar $\left(\mathrm{X}_{2}\right)$ sebesar 0,56 artinya apabila kebiasaan belajar $\left(\mathrm{X}_{2}\right)$ meningkat 1 poin maka akan terjadi pertambahan nilai pada hasil belajar matematika $(\mathrm{Y})$ sebesar 0,56 dengan asumsi motivasi belajar $\left(\mathrm{X}_{1}\right)$ tetap. Harga konstan pada persamaan tersebut sebesar 12, artinya hasil belajar matematika (Y) siswa akan meningkat sebesar 12 apabila nilai motivasi belajar $\left(\mathrm{X}_{1}\right)$ dan kebiasaan belajar $\left(\mathrm{X}_{2}\right)$ adalah nol. Besar pengaruh motivasi dan kebiasaan belajar terhadap hasil belajar matematika dapat dilihat dari koefisien determinasi yang menunjukkan nilai sebesar 0,252 atau $\mathrm{R}^{2}=25,2 \%$. Artinya motivasi dan kebiasaan belajar memberikan pengaruh secara bersama-sama sebesar $25,2 \%$ terhadap hasil 
belajar matematika dan sisanya 74,8\% dipengaruhi oleh variabel-variabel lain yang tidak diteliti dalam penelitian ini. Adapun pengaruh secara parsial (masingmasing) dari variabel motivasi dan kebiasaan belajar terhadap hasil belajar matematika berturut-turut diperoleh nilai sumbangan efektif (SE) yaitu 12,62\% dan $12,55 \%$. Dengan demikian dapat disimpulkan bahwa variabel motivasi $\left(\mathrm{X}_{1}\right)$ memiliki pengaruh lebih dominan terhadap variabel hasil belajar matematika (Y) dari pada variabel kebiasaan belajar $\left(\mathrm{X}_{2}\right)$. Untuk total sumbangan efektif (SE) adalah sebesar $25,2 \%$ atau sama dengan koefisien determinasi analisis regresi yakni $25,2 \%$.

Akan tetapi karakteristik nilai korelasi Guilford menunjukkan bahwa nilai determinasi sebesar 0,252 termasuk dalam karakteristik lemah artinya pengaruh yang diberikan motivasi dan kebiasaan belajar terhadap hasil belajar masih lemah. Artinya pengaruh motivasi dan kebiasaan belajar siswa untuk belajar matematika masih rendah. Namun, jika ditinjau dengan faktor lain, yang belum dijelaskan dalam penelitian ini bisa saja menambah pengaruh atau malah menurunkan pengaruh motivasi dan kebiasaan belajar terhadap hasil belajar matematika. Implikasi dari penelitian ini adalah semakin tinggi motivasi siswa dan semakin baik kebiasaan belajarnya maka akan dapat meningkatkan hasil belajar. Seorang siswa yang memiliki motivasi tinggi cenderung melakukan kebiasaan belajar yang baik khususnya dalam pelajaran metematika, akan memberikan peluang besar untuk memperoleh nilai yang tinggi dari hasil belajarnya. Dengan motivasi belajar yang tinggi dan kebiasan belajar yang baik maka siswa akan mendapatkan hasil belajar yang baik. Sehingga dapat disimpulkan bahwa terdapat pengaruh positif motivasi dan kebiasaan belajar siswa secara bersama-sama terhadap hasil belajar matematika.

\section{Penutup}

Berdasarkan hasil penelitian, analisis data, dan pembahasan yang telah diuraikan pada bab sebelumnya dapat ditarik kesimpulan:

1. Terdapat pengaruh positif dan signifikan motivasi belajar siswa terhadap hasil belajar matematika pada siswa kelas XI SMA Negeri 1 Jonggat tahun ajaran 2018/2019 dengan besar pengaruh 16,2\%. Persentase kategori motivasi belajar yaitu sangat tinggi, tinggi, sedang, randah dan sangat rendah berturut-turut $21,2 \%, 43,9 \%, 22,7 \%, 12,2 \%, 0$ dari 66 siswa yang diteliti.

2. Terdapat pengaruh positif dan signifikan kebiasaan belajar siswa terhadap hasil belajar matematika pada siswa kelas XI SMA Negeri 1 Jonggat tahun ajaran 2018/2019 dengan besar pengaruh 16,1\%. Persentase kategori kebiasaan belajar yaitu sangat baik, baik, cukup, kurang dan kurang sekali berturut-turut $21,2 \%, 27,3 \%, 36,4 \%, 12,1 \%, 3 \%$ dari 66 siswa yang diteliti. 
3. Terdapat pengaruh positif dan signifikan motivasi belajar dan kebiasaan belajar siswa secara bersama-sama terhadap hasil belajar matematika pada siswa kelas XI SMA Negeri 1 Jonggat tahun ajaran 2018/2019 dengan sumbangan efektif sebesar $25,2 \%$ dan sumbangan efektif masing-masing variabel berturutturut $12,62 \%$ dan $12,55 \%$.

Adapun saran yang dikemukakan peneliti dari penelitian ini adalah sebagai berikut: (1) bagi guru, oleh karena motivasi dan kebiasaan belajar berpengaruh positif terhadap hasil belajar matematika maka diharapkan guru dapat memberikan motivasi yang baik dan sesuai, sehingga siswa dapat menyadari manfaat belajar dan tujuan yang hendak dicapai dengan belajar tersebut. Selain itu guru juga diharapkan dapat mengawasi kebiasaan belajar siswanya agar siswanya mempunyai kebiasaan belajar yang baik, (2) bagi siswa, penelitian ini diharapkan dapat menjadi masukan bagi siswa bahwa dengan menanamkan motivasi belajar yang baik dan diikuti dengan kebiasaan belajar yang baik maka dapat meningkatkan hasil belajar matematika. Sehingga siswa diharapkan dapat mempertahankan motivasi dan kebiasaan belajar yang baik yang telah mereka lakukan dan bagi siswa yang memiliki motivasi belajar dan kebiasaan belajar yang kurang baik dapat menyadari bahwa hal tersebut masih bisa dirubah sehingga hasil belajar matematika yang diperoleh nantinya akan lebih baik, (3) bagi peneliti selanjutnya, agar bisa menjadikan penelitian ini menjadi sumber acuan maupun refrensi pada penelitian berikutnya.

\section{Referensi}

[1] Susanto, Ahmad. (2013). Teori Belajar Dan Pembelajaran Di Sekolah Dasar. Bandung: Kencana Prenada Media Group Algesindo.

[2] Sudjana. (2011). Dasar-Dasar Proses Belajar Mengajar. Bandung: Sinar Baru

[3] Sardiman. (2010). Interaksi dan Motivasi Belajar Mengajar. Jakarta: Rajawali Pers.

[4] Abror, Abd. Rachman. (1993). Psikologi Pendidikan. Yogyakarta: Tiara Wacana

[5] Herman, Hudoyo. (1990). Strategi Mengajar Belajar Matematika. Malang: IKIP Malang.

[6] Djaali. (2014). Psikologi Pendidikan. Jakarta: Bumi Aksara

[7] Sriwati. (2012). Pengaruh Motivasi Belajar terhadap Hasil Belajar Matematika Siswa Kelas XI SMA Bukit Barisan Padang 
e-ISSN 2715-1190

[8] Rosyadi. (2016). Pengaruh Motivasi Belajar dan Kebiasaan Belajar Terhadap Hasil Belajar Matematika. Skripsi. Tidak Diterbitkan. Universitas Wiralodra.

[9] Azainil. (2014). Pengaruh Motivasi Belajar dan Kebiasaan Belajar terhadap Hasil Belajar Matematika Siswa SMPN di Kecamatan Samarinda Utara. Skripsi. Tidak Diterbitkan. Universitas Mulawarman Samarinda. 